\title{
Pengaruh Budaya Organisasi, Kepemimpinan Transformasional Dan Spiritualitas Terhadap Kepuasaan Kerja Guru SDIT Bina Insani Kediri
}

\author{
Nurkolis \\ SDIslam TerpaduBina Insani Kediri
}

\begin{abstract}
Abstrak
Kepuasan kerja sebagai salah satu dimensi dari sikap kerja, dianggap penting oleh para praktisi manajemen personalia dan bagian pengembangan sumber daya manusia, adalah kaitannya dengan upaya meningkatkan kualitas kinerja (job performance) individu yang diharapkan berdampak terhadap peningkatan kinerja lembaga maupun organisasi. Penelitian ini termasukjenispenelitian kausal komparatif untuk mengetahui bagaimana pengaruh variabel bebas terhadap variabel terikat melalui variabel intervening. Pendekatan yang digunakam untuk menganalisis data hasil penelitian ini dengan menggunakan pendekatan kuantitatif yang menampilkan angka untuk menyimpulkan hasil penelitian.

Hasil penelitian menunjukkan yaitu 1) tidak Ada pengaruh antara Budaya Organisasi dengan kepuasan kerja guru SDIT Bina Insani, karena banyaknya guru baru yang dijadikan sampel pengujian, sehingga guru baru tersebut belum mempunyai persepsi yang baik tentang budaya organisasi, 2) tidak Ada pengaruh antara Kepemimpinan Transformasional dengan kepuasan kerja guru SDITBina Insani, karena selain dari banyaknya guru baru yang dijadikan sampel pengujian, juga karena masih kurangnya pembinaan yayasan kepada sisi leadership kepala sekolah, sehingga Kepemimpinan Transformasional belum berpengaruh signifikan kepada Kepuasan Kerja, 3) ada pengaruh antara Spiritualitas dengan kepuasan kerja guru SDITBina Insani, karena sebagai sekolah Islam, SDIT Bina Insani fokus kepada sisi Spiritualitas, terbukti dengan materi Pembinaan Yayasan, sebagian besar masih membahas sisi Spiritualitas tersebut, 4) ada pengaruh secara bersama-sama antara Budaya Organisasi, Kepemimpinan Transformasional dan Spiritualitasdengan kepuasan kerja guru SDIT Bina Insani, di mana hal ini sesuai dengan teori yang telah dipaparkan penulis.
\end{abstract}

\section{A. Latar Belakang Teoritis}

Di bidang pendidikan masalah kepuasan kerja guru (Teacher Job Satisfaction) merupakan salah satu variabel pada sikap kerja yang memerlukan perhatian dari pemangku kepentingan pendidikan, khususnya para pihak yang berkepentingan dengan usaha memahami perilaku kerja dan meningkatkan unjuk kerja para guru.

Kajian tentang kepuasan kerja guru makin penting karena. pertama. besarnya pengaruh sikap kerja terhadap disiplin, tingkat absensi, tingkat pindah kerja, komitmen kerja. semangat kerja, dan kinerja profesional seorang guru. Baik guru yang bekerja pada sekolah milik negara maupun pada sekolah yang dikelola oleh masyarakat. Kedua, diberlakukannya Undang-undang Guru dan Dosen sejak tahun 2003 yang salah satu butir pentingnya berupa pengakuan secara hukum pekerjaan guru sebagai sebuah profesi yang setara dengan profesi lain dengan segala implikasinya. Ketiga, asumsi yang mengarus utama di kalangan pengambil kebijakan bahwa salah satu solusi bagi masalah laten pendidikan adalah peningkatan kesejahteraan guru, perlu dibarengi dan didukung dengan usaha untuk memetakan profil guru yang lebih komprehensif melalui berbagai penelitian tematik yang terkordinasi tentang guru. Keempat, kepuasan kerja guru perlu diteliti mengingat sementara ini data empiris tentang kepuasan kerja guru dan aspek-aspek lain dari sikap atau kepuasan kerja guru di Indonesia, khususnya pada sekolah dasar Islam, dan lebih khusus lagi guru Sekolah Dasar Islam Terpadu (SDIT) Bina Insani di Kediri, masih sangat minim. Keterbatasan data ini mencakup baik ketersedian data maupun minimnya akses terhadap data yang mungkin telah ada. Oleh karena itu, penulis tertarik untuk menganalisa hubungan Budaya Organisasi, Kepemimpinan di SDIT Bina Insani dan Spritualitas para Guru terhadap Kepuasan Kerja para Guru SDIT Bina Insani.

Sebagai sebuah Yayasan Pendidikan yang sudah berumur sekitar 20 Tahun, maka sudah tentu telah terbangun Budaya Organisasi dalam Yayasan Bina Insani. Budaya organisasi merupakan system makna 
bersama yang dianut oleh anggota-anggota organisasi yang membedakan organisasi itu dengan yang lain, merupakan system nilai yang diperoleh dan dikembangan oleh organisasi, dan pola kebiasaan dan falsafah dasar pendiriannya, yang menjadi aturan dan pedoman dalam berfikir dan bertindak dalam mencapai tujuan organisasi. Namun selama ini, belum pernah diteliti Budaya Organisasi di Yayasan tersebut.

Budaya organisasi erat kaitannya dengan Kepemimpinan dalam yayasan tersebut. Bahwa peran kepemimpinan sangat penting dalam mengoptimalkan kinerja pegawai, selaras dengan pendapat Taylor dan Sieber (dalam Robbins 2006) yang menyatakan bahwa pemimpin menetapkan dan menyusun perannya dan peran bawahannya dalam mengupayakan pencapaian sasaran. Hal ini mencakup perilaku yang berupaya mengorganisasi kerja, hubungan kerja dan sasaran kerja.

Aspek Kepemimpinan bila dikaitkan dengan Spiritualitas. jikalau pimpinanBina Insani memiliki spiritualitas yang tinggi. tentunya segala apa yang ia kerjakan akan selalu dipandang sebagai bentuk ibadah kepada Allah SW'T .

Dengan memperhatikan seluruh uraian latar belakang di atas. maka penelitian mengambil judul : Pengaruh Budaya Organisasi. Kepemimpinan Transformasional Dan Spiritualitas terhadap Kepuasan Kerja Guru Sekolah Dasar Islam Terpadu Bina Insani kediri.

\section{Budaya Organisasi}

Robbins (2003) menuliskan budaya organisasi merupakan sebuah persepsi umum yang dipegang oleh anggota organisasi, suatu sistem rentang keberartian bersama. Budaya organisasi berkepentingan dengan bagaimana pekerja merasakan karakteristik suatu budaya organisasi, tidak dengan apakah seperti mereka atau tidak. Sedangkan menurut Michael Zwell (2000) menyatakan budaya korporasi sebagai tata hidup suatu organisasi yang diberikan melalui generasi penerus pekerja. Dari pengertian dan sudut pandang tersebut dapat ditarik sebuah kesimpulan dimana budaya organisasi adalah filosofi dasar organisasi yang memuat keyakinan, norma - norma, dan nilai - nilai tersebut menjadi pegangan semua sumber daya manusia dalam organisasi dan melaksanakan kinerjanya.

Berdasarkan hasil penelitian Hofstede, Greet, Michael Harris Bond dan Chung Leung Luk yang berjudul "Individual Perception Of Organizational Cutures : $A$ Methodological On Levels of Analysis (1993)terdapat 6 karakteristik dalam suatu budaya perusahaan, yaitu : profesionalisme, jarak dari management, percaya pada rekan sekerja, keteraturan, permusuhan dan integrasi. Penelitian ini merupakan analisa ulang terhadap kajian tentang "organizational culture" yang telah dilakukan sebelumnya, dimana saat ini lebih memfokuskan masalah pada level individual dari pada ecological level.

\section{Kepemimpinan Transformasional}

Kepemimpinan transformasional adalah gaya kepemimpinan yang digunakan oleh seseorang manajer bila ia ingin suatu kelompok melebarkan batas dan memiliki kinerja melampaui status quo atau mencapai serangkaian sasaran organisasi yang sepenuhnya baru. Kepemimpinan transformasional pada prinsipnya memotivasi bawahan untuk berbuat lebih baik dari apa yang bisa dilakukan, dengan kata lain dapat meningkatkan kepercayaan atau keyakinan diri bawahan yang akan berpengaruh terhadap peningkatan kinerja. (O'Leary 2001)

Menurut Wutun (2001) salah satu konsep kepemimpinan yang dapat menjelaskan secara tepat pola perilaku kepemimpinan atasan yang nyata ada dan mampu memuat pola-pola perilaku dari teori kepemimpinan lain adalah kepemimpinan transformasional dari Bass. Bass (dalam Wutun, 2001), menyatakan bahwa gaya kepemimpinan transformasional cenderung membangun kesadaran para bawahannya mengenai pentingnya nilai kerja dan tugas mereka. Pemimpin berusaha memperluas dan meningkatkan kebutuhan melebihi minat pribadi serta mendorong perubahan tersebut ke arah kepentingan bersama termasuk kepentingan organisasi (Wutun, 2001).

Menurut Bass dan Avolio (1990, dalam Suryanto, 2005) menemukan bahwa kepemimpinan transformasional memiliki empat komponen perilaku, yaitu

1. Idealized Influence adalah perilaku seorang pemimpin transformasional yang memiliki keyakinan diri yang kuat, 
selaluhadir di saat-saat sulit, memegang teguh nilai-nilai moral, menumbuhkan kebanggaan pada pengikutnya, yang bervisi jelas, dan langkah-langkahnya selalu mempunyai tujuan yang pasti, dan agar bawahan mau mengikutinya secara suka rela, ia menempatkan dirinya sebagai tauladan bagi para pengikutnya tersebut.

2. Individualized Consideration, adalah perilaku pemimpin transformasional, di mana ia merenung, berpikir, dan selalu mengidentifikasi kebutuhan para bawahannya, berusaha sekuat tenaga mengenali kemampuan karyawan, membangkitkan semangat belajar pada para karyawannya, memberi kesempatan belajar seluas-luasnya, selalu mendengar bawahannya dengan penuh perhatian, dan baginya adalah kunci kesuksesan sebuah karya.

3. Inspirational Motivation, adalah upaya pemimpin transformasional dalam memberikan inspirasi para pengikutnya agar mencapai kemungkinankemungkinan yang tidak terbayangkan, ditantangnya bawahan mencapai standar yang tinggi. Pemimpin transformasional akan mengajak bawahan untuk memandang ancaman dan masalah sebagai kesempatan belajar dan berprestasi. Oleh karenanya, pemimpin transformasional menciptakan budaya untuk berani salah, karena kesalahan itu adalah awal dari pengalaman belajar segala sesuatu. Bagi pemimpin transformasional kata adalah senjata utamanya, dengan 'kata' pula ia bangkitkan semangat bawahan. Pemimpin transformasional akan menggunakan simbol-simbol dan metafora untuk memotivasi mereka, bicara dengan antusias dan optimis.

4. Intellectual Stimulation. Imajinasi, dipadu dengan intuisi namun dikawal oleh logika dimanfaatkan oleh pemimpin ini dalam mengajak bawahan berkreasi. Pemimpin transformasional berusaha mengajak bawahan untuk berani menentang tradisi uang, dan mengajak pula bawahan untuk bertanya tentang asumsi lama. Pemimpin transformasional menyadari bahwa sering kali kepercayaan tertentu telah menghambat pola berpikir, oleh karenanya, pemimpin transformasional mengajak bawahannya untuk mempertanyakan, meneliti, mengkaji dan jika perlu mengganti kepercayaan itu.

\section{Spiritualitas}

Spiritualitas (spirituality) didefinisikan sebagai salah satu aspek dari eksistensi kemanusiaan yang berhubungan dengan struktur atau unsur penting (Tuhan) yang memberikan makna (meaning) dan arah (directions) kepada kehidupan seseorang yang membantunya dalam menghadapi perubahanperubahan eksistensial dalam hidup maupun Kerja. Berhubungan dengan pencarian manusia terhadap makna(meaning), tujuan (purpose), pengetahuan tentang transendensi diri (self transcending knowledge), hubungan yang penuh makna (meaningful relation- ship), perasaan cinta dan kesucian (sense of holy) yang berhubungan dengan sistem beragama (religious system). Proses tumbuhnya spiritualitas ini diawali oleh ketulusan, hubungan timbal balik dan nilai yang kuat, yang muncul dari perasan bermakna yang menyatu pada Kerja, pengakuan terhadap keterbatasan diri dan ketidak terbatasan kekuasaan Tuhan yang menjadi sebab munculnya motivasi yang tinggi, kinerja yang hebat, serta kepuasan terhadap pekerjaannya.

Dimensi-dimensi dari spiritualitas dikemukakan oleh Swinton (2001) sebagaimana dikutip oleh Gilbert (2007), mencakup aspek-aspek atau dimensi Meaning (Pemaknaan), Dimensi Value (Nilai dan keyakinan), Dimensi Trancendence (Transendensi), Dimensi Connecting (Keterhubungan), dan dimensi Becoming (proses menjadi)

\section{Kepuasan Kerja}

Robbins (2001) mendefinisikan kepuasan kerja (Job Satisfaction) sebagai sikap umum seorang pekerja terhadap pekerjaanya yang dikenali dari "perbedaan antara jumlah penghargaan (rewards) yang mereka terima dengan rewards yang mereka yakini seharusnya mereka terima"

Aspek-aspek kepuasan kerja terdiri dari aspek instrinsik dan ekstrinsik yaitu ; aspek karakteristik pekerjaan (work), Gaji dan benefit-benefit (pay-benefits), promosi (promotion), rekognisi (recognition), kondisi 
lingkungan kerja (working conditions), rekan kerja (co-worker), dan supervisi atasan (supervision). Aspek-aspek kepuasan kerja terdiri dari aspek instrinsik dan ekstrinsik yaitu ; aspek karakteristik pekerjaan (work), Gaji dan benefit-benefit (pay-benefits), promosi (promotion), rekognisi (recognition), kondisi lingkungan kerja (working conditions), rekan kerja (co-worker), dan supervisi atasan (supervision).

\section{B. Metode Penelitian}

Penelitian ini termasukjenispenelitian kausal komparatif untuk mengetahui bagaimana pengaruh variabel bebas terhadap variabel terikat melalui variabel intervening. Pendekatan yang digunakam untuk menganalisis data hasil penelitian ini dengan menggunakan pendekatan kuantitatif yang menampilkan angka untuk menyimpulkan hasil penelitian.

\section{Subyek dan Obyek Penelitian}

1. Subyek penelitian ini adalah Guru Sekolah Dasar Islam Terpadu Kediri.

2. Dalam penelitian ini yang menjadi obyek penelitian adalah Budaya Organisasi, Kepemimpinan Transformasional, Spiritualitas, kepuasan kerja Guru Sekolah Dasar Islam Terpadu Bina Insani Kediri. .

\section{Populasi dan Sampel}

Populasi penelitian ini adalah Guru Sekolah Dasar Islam Terpadu Bina Insani Kediri berjumlah 63 orang.

Sampel yang diambil dalam penelitian ini adalah sama dengan populasi, yakni 63 orang Guru Sekolah Dasar Islam Terpadu Bina Insani Kediri dengan teknik pengambilan sampel yaitu teknik sampling tuntas dengan mengambil seluruh anggota populasi menjadi sampel dalam penelitian ini.

\section{Variabel dan Definisi Operasional}

\section{Varibel}

Variabel penelitian ini adalah terdiri dari :

(1) Budaya Organisasi $\left(X_{1}\right)$

(2) Kepemimpinan Transformasional $\left(\mathrm{X}_{2}\right)$

(3) Spiritualitas $\left(\mathrm{X}_{3}\right)$

(4) Kepuasan Kerja (Y)

Definisi Operasional

Definisi oprasional dari varibel-variabel tersebut adalah :

\section{Budaya Organisasi}

Untuk mengukur variabel ini digunakan indikator Budaya Organisasi sesuai yang disampaikan oleh Teori Greert, Michael Harris Bond dan Chung - Leung Luk yaitu:

1. Profesionalisme

2. Jarak dengan manajemen

3. Percaya dengan rekan keja

4. Keteraturan

5. Permusuhan

6. integrasi

\section{Kepemimpinan Transformasional}

Untuk mengukur variabel ini digunakan indikator Bass Avolio dalam Suryanto (2005) yaitu :

1. Pengaruh Ideal

2. Pertimbangan Individu

3. Motivasi inspirasional

4. Stimulasi Intelektual

\section{Spiritualitas}

Penelitian ini menggunakan indikator dari Swinton (2001) Gilbert (2007) yaitu:

1. Makna dan tujuan hidup

2. Nilai keyakinan dan kepercayaan

3. Transendensi

4. Keterhubungan

5. Proses menjadi

Selanjutnya peneliti melakukan uji validitas dan uji reabilitas instrumen sebagai suatu cara uji coba yang mennjukkan tingkat kevalidan dan reabilitas suatu instrumen. Dalam penelitian ini peneliti menggunakan teknik analisa regresi berganda dan anlalisa jalur yang dikembangkan dalan aplikasi SPSS ( Statistical Product and Service solution), yaitu teknik statistik yang dapat digunakan untuk menggambarkan hubungan antar item setiap faktor dalam variabel.

Setelah data dari responden terkumpul maka dilakukan pengujian hipotesis seperti yang sudah dirumuskan sebelumnya. Sehingga diperoleh data yang bersifat kuantitatif yaitu data berupa angka. Analisis data merupakan inti dari penelitian yang artinya bahwa dengan menganalisis data, peneliti dapat membuktikan diterima atau ditolaknya hipotesis yang telah peneliti ajukan di awal penelitian. Dalam penelitian ini dilakukan analisis deskriptif dan analisis inferensial melalui Uji t, Uji F, Koefisien Determinasi atau $\mathrm{R}$ Square, Uji Instrumen yaitu uji validitas dan uji reabilitas, Uji 
Asumsi Klasik yaitu uji normalitas, uji multikolinearitas, uji heterokedastisitas., analisa regresi berganda.

\section{Hasil Penelitian Dan Pembahasan \\ Analisis Uji Asumsi Klasik}

\begin{tabular}{|c|c|}
\hline Uji Asumsi Klasik & Hasil Uji \\
\hline Uji Normalitas & $\begin{array}{l}\text { Grafik P-Plot menunjukkan titik-titik menyebar di sekitar } \\
\text { garis diagonal serta penyebarannya mengikuti arah garis } \\
\text { diagonal. Hasil uji normalitas tersebut sesuai dengan } \\
\text { pendapat Santoso (2002) yang menyatakan bahwa " jika } \\
\text { datanya menyebar di sekitar garis diagonal dan mengikuti } \\
\text { arah garis diagonal, maka model regresi memenuhi asumsi } \\
\text { normalitas" }\end{array}$ \\
\hline Uji Heteroskedastisitas & $\begin{array}{l}\text { Grafik Scatter-Plot menunjukkan titik-titik menyebar secara } \\
\text { acak, tidak membentuk sebuah pola tertentu yang jelas, serta } \\
\text { tersebar baik di atas maupun di bawah angka } 0 \text { pada sumbu } \\
\text { Y, maka dapat disimpulkan tidak terjadi heteroskedastisitas } \\
\text { pada model regresi ini. }\end{array}$ \\
\hline Uji Multikolinearitas & $\begin{array}{l}\text { Nilai Tolerance variabel Budaya Organisasi } \\
0,637 \text {, Kepemimpinan Transformasional } 0,952 \text {, Spiritualitas } \\
0,632 \text { atau Tolerance }>0,10 \text {. Nilai VIF Budaya Organisasi } \\
\text { 1,571, Kepemimpinan Transformasional 1,051, Spiritualitas } \\
\text { 1,584 atau VIF < 10. Disimpulkan tidak terjadi } \\
\text { multikolinearitas antar variabel bebas. }\end{array}$ \\
\hline
\end{tabular}

\section{Analisis Regresi Linear Berganda}

\section{Coefficients $^{\mathrm{a}}$}

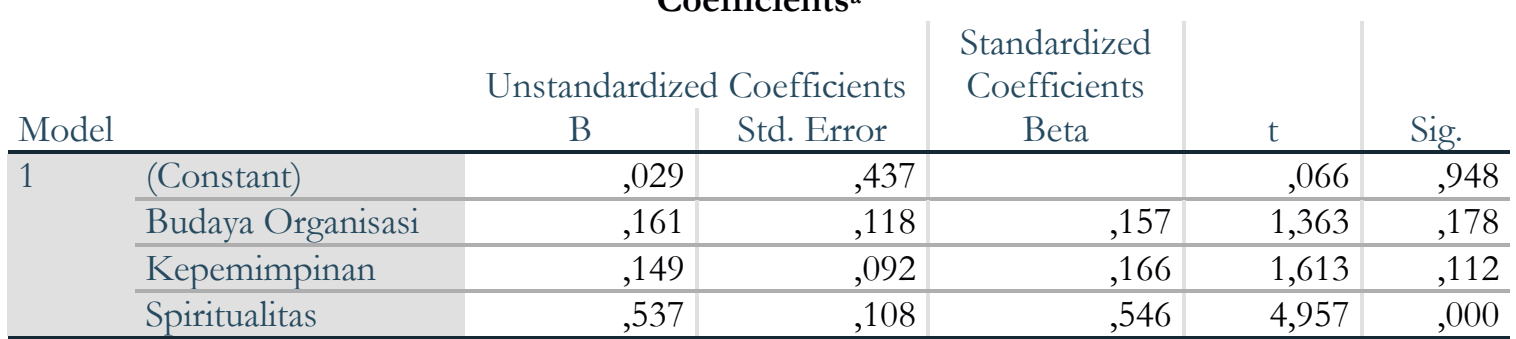

a. Dependent Variable: Kepuasan Kerja

Pada tabel Coefficients terlihat nilai $\mathrm{t}$ untuk setiap variabel independen, yaitu Budaya Organisasi $=1,363$, Sig. 0,178, Kepemimpinan Transformasional $=1,613$,
Sig. 0,112 dan Spiritualitas $=4,957$. Nilai sig. $=0,000$. Selanjutnya nilai $\mathrm{t}$ hitung tersebut dibandingkan dengan nilai $\mathrm{t}$ tabel. Jika nilai $\mathrm{t}$ hitung $>\mathrm{t}$ tabel atau nilai sig. $<0,05$, maka tidak 
terdapat pengaruh parsial (sendiri) variabel independen (X1, X2,)dan terdapat pengaruh parsial (sendiri) variabel independen X3 terhadapvariabel dependen (Y). Hasilnya, variabel Budaya Organisasi nilai thitung $1,363<$ $\mathrm{t}$ tabel 2,000, variabel Kepemimpinan Trasformasionalnilai t-hitung 1,613 < tabel 2,000, dan variabel Spiritualitas nilai t hitung $4,957>$ t tabel 2,000. Nilai sig. pada variabel bebas juga $<0,05$.

Selanjutnya untuk melihat ada tidaknya pengaruh variabel independen secara simultan terhadap variabel dependen dapat di analisa pada tabel Anova kolom F. Terlihat nilai $\mathrm{F}$ hitung 24,970 > F tabel 2.79 dengan signifikansi pada kolom sig. $0,000<$ 0,05 sehingga dapat disimpulkan bahwa terdapat pengaruh variabel independen $(\mathrm{X} 1$, $\mathrm{X} 2$, X3) secara simultan terhadap variabel dependen (Y). Dengan memperhatikan hasil pengolahan data pada tabel Model Summary, diketahui nilai $\mathbf{R}$ square sebesar $\mathbf{0 , 5 5 9}$, artinya bahwa variabel independen (X1, $\mathrm{X} 2$, X3) berpengaruh secara simultan terhadap variabel dependen (Y) sebesar $55,9 \%$.

Hubungan antara ketiga variabel bebas tersebut dan pengaruhnya terhadap kepuasan kerja dapat digambarkan dalam model persamaan sebagai berikut :

$$
\begin{gathered}
\mathrm{Y}=\beta_{0}+\beta_{1} \mathrm{X}_{1}+\beta_{2} \mathrm{X}_{2}+\beta_{3} \mathrm{X}_{3} \\
\mathrm{Y}=0,029+ \\
0,157 \mathrm{X}_{1}+ \\
0,166 \mathrm{X}_{2}+ \\
0,546 \mathrm{X}_{3}
\end{gathered}
$$

$\mathrm{Y}=$ tingkat kepuasan Kerja Guru

$\mathrm{X} 1$ = unsur Budaya Organisasi, yang

diambil dari nilai rata-rata Budaya
Organisasi dalam survei Kepuasan Kerja.

$\mathrm{X} 2=$ unsur Kepemimpinan

Transformasional, yang diambil dari nilai rata-rata unsur-unsur pembentuk Kepemimpinan Transformasional dalam survei kepuasan kerja.

$\mathrm{X} 3$ = unsur Spiritualitas atau tarif, yang diambil dari nilai rata-

\begin{tabular}{|c|c|c|}
\hline Variabel & Uji t & Uji F \\
\hline $\begin{array}{l}\text { Budaya } \\
\text { Organisasi }\end{array}$ & $1,363<2,000$ & $24,970>2,79$ \\
\hline $\begin{array}{l}\text { Kepemimpinan } \\
\text { Transformasional }\end{array}$ & $1,613<2,000$ & \\
\hline Spiritualitas & $4,957>2,000$ & \\
\hline \multicolumn{3}{|c|}{$\begin{array}{l}*_{\mathrm{t}} \text { tabel }=2,000 \quad \mathrm{~F} \text { tabel }=2,79 \\
*_{\mathrm{t}} \text { hitung }>\mathrm{t} \text { tabel }=\text { terdapat pengaruh } \\
\text { parsial } \\
{ }^{*} \mathrm{~F} \text { hitung }>\text { F tabel }=\text { terdapat pengaruh } \\
\text { simultan }\end{array}$} \\
\hline
\end{tabular}
rata unsur-unsur pembentuk Spiritualitas dalam survei kepuasan kerja.

Tabel 4.26. Rangkuman Hasil Uji t dan Uji F

Tabel 4.27. Hasil Penelitian terhadap Hipotesis

\begin{tabular}{|l|l|c|c|}
\hline \multicolumn{3}{|c|}{ Hipotesis } & Hasil Penelitian \\
\hline $\mathbf{H 1}$ & $\begin{array}{l}\text { Ada pengaruh antara Budaya Organisasi } \\
\text { dengan kepuasan kerja guru SDITBina } \\
\text { Insani }\end{array}$ & Tidak Signifikan \\
\hline $\mathbf{H 2}$ & $\begin{array}{l}\text { Ada pengaruh antara Kepemimpinan } \\
\text { Transformasional dengan kepuasan kerja } \\
\text { guru SDITBina Insani }\end{array}$ & Tidak Signifikan \\
\hline
\end{tabular}




\begin{tabular}{|l|l|l|}
\hline H3 & $\begin{array}{l}\text { Ada pengaruh antara Spiritualitas dengan } \\
\text { kepuasan kerja guru SDITBina Insani }\end{array}$ & Sesuai hipotesis \\
\hline $\mathbf{H 4}$ & $\begin{array}{l}\text { Ada pengaruh antara Budaya Organisasi, } \\
\text { Kepemimpinan Transformasional dan } \\
\text { Spiritualitasdengan kepuasan kerja guru } \\
\text { SDIT Bina Insani }\end{array}$ & Sesuai hipotesis \\
\hline
\end{tabular}

Dari Tabel coeffisient hasil dari Uji Regresi berganda, dapat diambil kesimpulan sebagai berikut:

1. Budaya organisasi tidak mempengaruhikepuasankerja dengan nilai $\mathrm{t}$ hitung $1,363<\mathrm{t}$ tabel $(2.000)$ dengan sig. $0,178>0,05$ artinyatidak signifikan. Dengan demikian, hipotesis H1 bahwa Budaya organisasi berpengaruh positif dan signifikan terhadap kepuasan kerja ditolak. Hal ini dapat dijelaskan, bahwa jumlah responden sebanyak 63 orang, jumlah guru tetap sebanyak 23, Guru Tidak tetap 21, sedangkan guru baru sebanyak 19 orang. Dengan jumlah guru baru dan guru tidak tetap yang melebihi jumlah guru tetap, maka bisa difahami bahwa Budaya organisasi belum berpengaruh signifikan kepada kepuasan kerja, karena sebagian besar responden adalah guru baru dan guru tidak tetap.

2. Kepemimpinan Transformasional tidak mempengaruhikepuasankerja dengan nilai $\mathrm{t}$ hitung $1,613<\mathrm{t}$ tabel $(2.000)$ dengan sig. $0,112>0,05$ artinyatidak signifikan. Dengan demikian, hipotesis H2 bahwa Kepemimpinan Transformasional berpengaruh positif dan signifikan terhadap kepuasan kerja ditolak. Hal ini dapat dijelaskan, bahwa berdasarkan wawancara penulis kepada pihak SDM Yayasan Bina Insani, dapat diambil kesimpulan bahwa Pembinaan Yayasan kepada para Kepala sekolah masih kurang, masih 2 bulan sekali, dan sisi leadership masih belum dikembangkan secara optimal, sehingga Kepemimpinan Transformasional masih dirasa belum signifikan berpengaruh kepada Kepuasan Kerja.

3. Spiritualitas Berpengaruh secara parsial mempengaruhikepuasankerja dengan nilai $\mathrm{t}$ hitung 4,957> t tabel (2.000) dengan sig. $0,000<0,05$ artinyasignifikan. Dengan demikian, hipotesis H3 bahwaSpiritualitas berpengaruh positif dan signifikan terhadap kepuasan kerja diterima. Sesuai degan hasil wawancara penulis dengan pihak SDM bahwa Pembinaan Guru masih fokus pada pembinaan Spiritual.

4. Hipotesis 4 yang berbunyi Ada pengaruh antara Budaya Organisasi, Kepemimpinan Transformasional dan Spiritualitasdengan kepuasan kerja guru SDIT dapat diterima dengan nilai uji $\mathrm{F}$ sebesar 24,970> Ftabel 2,79.

Implikasi hasil Penelitian

Hasil analisis terhadap faktor-faktor yang berpengaruh terhadap tingkat kepuasan Kerja Guru SDIT Bina Insani menunjukkan bahwa Pihak Yayasan Bina Insani harus memberikan perhatian khusus terhadap beberapa hal, yaitu :

1. Terus memperbaiki kualitas pembinaan Guru SDIT Bina Insani, terutamanya Sisi Budaya Organisasi dan pembinaan Kepemimpinan Kepala Sekolah, sehingga dapat secara signifikan meningkatkan kepuasan Guru.Dengan keterbukaan dan transparansi serta tetapmempertahankanjalinanhubungan denganGurumelaluiacarasosial yangmelibatkanseluruh Guru tentu akan meningkatkan Kepuasan Kerja Guru. 
2. Peningkatan kapasitas Kepemimpinan Transformasional Kepala Sekolah dan Pengurus Yayasan harus terus ditingkatkan dengan pembinaan leadership. Salah satu cara yang dapat ditempuh adalah melalui pelatihan dan capacity building baik dari sisi pemahaman tentang Kepemimpinan Transformasional, maupun dari aspek implementasi Kepemimpinan Transformasional.

\section{Kesimpulan dan Rekomendasi}

Dari hasil penelitian yang dilakukan dan pembahasan pada bab sebelumnya, maka dapat ditarik kesimpulan bahwa:

1. Tidak Ada pengaruh antara Budaya Organisasi dengan kepuasan kerja guru SDIT Bina Insani, karena banyaknya guru baru yang dijadikan sampel pengujian, sehingga guru baru tersebut belum mempunyai persepsi yang baik tentang budaya organisasi.

2. Tidak Ada pengaruh antara Kepemimpinan Transformasional dengan kepuasan kerja guru SDITBina Insani, karena selain dari banyaknya guru baru yang dijadikan sampel pengujian, juga karena masih kurangnya pembinaan yayasan kepada sisi leadership kepala sekolah, sehingga Kepemimpinan Transformasional belum berpengaruh signifikan kepada Kepuasan Kerja.

3. Ada pengaruh antara Spiritualitas dengan kepuasan kerja guru SDITBina Insani, karena sebagai sekolah Islam, SDIT Bina Insani fokus kepada sisi Spiritualitas, terbukti dengan materi Pembinaan Yayasan, sebagian besar masih membahas sisi Spiritualitas tersebut.

4. Ada pengaruh secara bersama-sama antara Budaya Organisasi, Kepemimpinan Transformasional dan Spiritualitasdengan kepuasan kerja guru SDIT Bina Insani, di mana hal ini sesuai dengan teori yang telah dipaparkan penulis.

\section{Rekomendasi}

1. Pembinaan kepada Guru SDIT Bina Insani harus lebih ditingkatkan, baik frekwensi dan muatannya, selain tetap membahas sisi spiritual, tidak kalah pentingnya yaitu upaya peningkatan sisi Budaya Ornganisasi dan Kepemimpinan Kepala Sekolah.

2. Hendaknya Induk Organisasi Sekolah Islam Terpadu membuat materi pembinaan yang fokus kepada Manajemen Organisasi dan Leadership untuk peningkatan Kapasitas Guru dan Yayasan.

3. Komitmen organisasional tidak berpengaruh pada kepuasan kerja. Hal ini disebabkan oleh banyaknya guru baru dengan status guru tidak tetap. Oleh karena itu ke depan, penelitian sebaiknya ditujukan kepada responden guru tetap dan atau guru yang memiliki masa kerja lebih dari sepuluh tahun.

\section{E. Daftar Pustaka}

Bass,B.M.(1990). From transactional to transformasional leadership: Learning to share the vision.Organizational Dynamics,18(3),19-31.

Hofstede, G., Bond, M.H. and Luk, C.-L. 1993 'Individual Perceptions of Organizational Cultures: Amethodological Treatiseon LevelsofAnalysis', OrganizationStudies.

Hofstede, Geert. 1986. Culture's Consequences, International Differences inWork- Related $V$ alues.London: SagePublications

Kreitner, Robert \& Kinicki., Anggelo. 2005. Perilaku Organisasi. Jakarta : Salemba Empat.

Robbins,S.P.(2006). Perilaku organisasi. Jakarta: Indeks.

Robbins, S.P., \& Timothy,A.J. (2007). Organizational behavior .NewJersey: PearsonEducation, Inc.

Robbins,S.P.,\&Judge,T.A.(2008).Organizationa Ibehavior(12 ${ }^{\text {th }}$ ed).NewJersey:PearsonEd ucation,Inc.

Robbins,S.P.,\&Judge,T.A.(2009).Organizationa Ibehavior (13 ${ }^{\text {th }}$ ed).NewJersey:PearsonEd ucation,Inc.

Sedarmayanti. 2007. Manajemen Sumber Daya Manusia, cetakan pertama. Bandung : PT.Refika Aditama.

Stone,R.J.(2005).Humanresourcemanagement. Australia: JohnWiley\&Sons Australia,Ltd. 
Suwatno, H., \& Priansa,D.J. (2011). Manajemen SDM dalam organisasi publik dan bisnis. Bandung: Alfabeta.

Tondok, M.S.\&Andarika,R. (2004). Hubungan antara persepsi gaya kepemimpinan transformasional dan transaksional dengan kepuasan kerja karyawan,Jumal Psikologi,Palembang,1(1). 